\title{
Dynamics of Insulin Release by Perfused Edible Dormouse (Glis glis) Pancreas
}

\author{
Seasonal Variations \\ Ch. Castex and B. Ch. J. Sutter \\ Laboratoire d'Endocrinologie, Université de Bordeaux I, U.E.R. de Biologie, Talence, France
}

Summary. In order to characterize seasonal variations of beta cell function in the edible dormouse (Glis glis), the dynamics of insulin release were examined during perfusion of the isolated pancreas. The B cells exhibited biphasic insulin secretion; however, the dynamic response differed from that of the rat in that there was a steady-state second release phase. Glucose-induced insulin release changed according to the seasons. With $16.8 \mathrm{mmol} / \mathrm{l}$ glucose, the average insulin release of the late phase was 30.8 $\pm 12.6 \mathrm{ng} / \mathrm{min}$ in winter, $7.4 \pm 3.2 \mathrm{ng} / \mathrm{min}$ in spring, $13.1 \pm 3 \mathrm{ng} / \mathrm{min}$ in summer and $23.3 \pm 4.4 \mathrm{ng} / \mathrm{min}$ in autumn. The glucose-induced insulin release, expressed as percent of the insulin content of the pancreas, varied according to the season: it represented $2.23 \pm 0.31 \%$ in winter, $1.28 \pm 0.10 \%$ in spring, $1.56 \pm 0.15$ in summer and $2.6 \pm 0.11$ in autumn. It is suggested that in spring and summer, the edible dormouse B cell secretion mechanism is less sensitive to glucose than in the other seasons.

Key words: Edible dormouse (Glis glis), hibernating mammal, dynamics of insulin release, insulin secretion, glucose-stimulated insulin secretion, perfused pancreas, $B$ cell, seasonal variations.

Glucose tolerance tests performed in the edible dormouse have shown seasonal variations in the plasma insulin response, associated with glucose tolerance changes [1]. In autumn and in winter, the glucoseinduced plasma insulin concentrations are increased and insulin regulates the high peripheral consumption of this hexose; at the beginning of spring, it decreases and glucose tolerance is impaired. In June plasma insulin levels are low and poor glucose tolerance persists.
Glucose tolerance tests give useful information about glucose effects on B cell function. In vivo tests are limited however, in that insulin secretagogues could act through secondary effects rather than through a direct action on the B cell [2]. In order to circumvent this problem and to discover if seasonal variations of plasma insulin levels after glucose loading are due to variations of insulin secretion, we have studied insulin secretion of the perfused pancreas of the edible dormouse and compared values with those found in the rat.

\section{Material and Methods}

\section{Animals}

Adult male and female edible dormice were captured in August and September, and kep $₫$ throughout the year inside large cages placed in a room open to the external climatic conditions. They were fed ad libitum with apples and sunflower seeds. Dormice were acclimatized for 4-5 months to captivity and experiments started in January. The experimental seasons were January for winter, May for spring, July for summer, the end of October and the beginning of November for autumn. The average body weight of the group was: $140 \pm 3 \mathrm{~g}(\mathrm{n}=25)$ in winter; $148 \pm 4 \mathrm{~g}(\mathrm{n}=$ $18)$ in spring; $138 \pm 3 \mathrm{~g}(\mathrm{n}=23)$ in summer; $145 \pm 5 \mathrm{~g}(\mathrm{n}=23)$ in autumn. Insulin secretion of the dormouse pancreas was compared with that of Wistar rats (CF Strain of the CNRS), weighing $200-250 \mathrm{~g}$, which were housed in a thermostated $\left(22^{\circ} \mathrm{C}\right)$ lightcontrolled room ( $12 \mathrm{~h}$ darkness, $12 \mathrm{~h}$ light) with access to food and water ad libitum.

\section{Perfusion Technique}

The anatomy and vasculature of the edible dormouse pancreas are identical to those of the rat. The surgical technique used for the two preparations were modifications of the technique described by Penhos et al. [3]. Anaesthesia was induced with IP sodium amylobarbital (Eunoctal, I.S.H. Laboratory, Paris) $10 \mathrm{mg} / 100 \mathrm{~g}$ body weight. The abdominal cavity was opened through a midline incision extending from the suprapubic region to the xiphoid process. 
Table 1. Seasonal variations of weight and insulin content in edible dormouse pancreas. Number of animals are shown in parentheses. Results are given as mean values $\pm \mathrm{SEM} \star p<0.05 ; \star \star p<0.01 ; \star \star \star p<0.001$ between seasons by Student's $\mathrm{t}$ test

\begin{tabular}{|c|c|c|c|c|c|c|c|}
\hline & & Winter & & Spring & Summer & & Autumn \\
\hline \multirow[t]{2}{*}{$\begin{array}{l}\text { Pancreas } \\
\text { weight }\end{array}$} & $\mathrm{mg}$ & $\begin{array}{c}452 \pm 34 \\
(10)\end{array}$ & $\star$ & $\begin{array}{c}321 \pm 40 \\
(10)\end{array}$ & $\begin{array}{c}288 \pm 19 \\
(10)\end{array}$ & $\star \star \star \star$ & $\begin{array}{c}557 \pm 33 \\
(11)\end{array}$ \\
\hline & $\begin{array}{l}\% \text { of body } \\
\text { weight }\end{array}$ & $0.31 \pm 0.02$ & $\star$ & $0.22 \pm 0.02$ & $0.22 \pm 0.01$ & $\star \star \star$ & $0.44 \pm 0.03$ \\
\hline $\begin{array}{l}\text { Insulin } \\
\text { content }\end{array}$ & $\mu \mathrm{g} /$ pancreas & $\begin{array}{c}80.4 \pm 13.2 \\
(6)\end{array}$ & $\star \star$ & $\begin{array}{c}34.4 \pm 4.4 \\
(6) \\
\uparrow\end{array}$ & $\begin{array}{c}46.0 \pm 6.4 \\
(6) \\
\end{array}$ & & $\begin{array}{c}50.8 \pm 4.8 \\
(11) \\
\uparrow\end{array}$ \\
\hline
\end{tabular}

A second incision extended at right angles to the initial midline incision in the midlumbar region. The branches of the splenic artery and vein were ligated to remove the spleen. Then the left gastric artery and vein were ligated. The gastric branches of the right and left gastroepiploic artery and vein, which paralleled the superior margin of the pancreas and the greater curvature of the stomach were ligated collectively in small groups. The duodenum was separated from the pancreas with two little clamps. The abdominal aorta was exposed; the superior mesenteric artery and the coeliac axis were kept intact. The abdominal aorta was first ligated between the superior suprarenal artery and the coeliac axis, and then cannulated between the superior mesenteric artery and the coeliac axis. The hepatic artery and portal vein were ligated before the portal vein was cannulated to collect the pancreatic venous effluent. A telethermostatic recorder was then inserted near the pancreas, to measure temperature throughout the experiment. Operative time was approximatively twenty minutes. Rat and dormouse pancreases were perfused with Krebs-Ringer bicarbonate medium at a flow rate of $1 \mathrm{ml} / \mathrm{min}$ by a peristaltic pump. The medium was supplemented with $0.25 \%$ bovine crystallised albumin (Sigma) and was continuously gassed with a mixture of $\mathrm{O}_{2}$ and $\mathrm{CO}_{2}(95: 5)$; the resulting $\mathrm{pH}$ was 7.4 . Arterial pressure was recorded and was found to vary between 20 and $40 \mathrm{mmHg}$ between preparations. In those preparations in which oxygen consumption was determined, arterial and venous perfusate specimens were collected anaerobically and the $\mathrm{O}_{2}$ concentration was measured with a Radiometer $\mathrm{pO}_{2}$ electrode. Oxygen consumption was $4 \mu \mathrm{l} / \mathrm{min} /$ pancreas in both species. The pancreas was first perfused for $30 \mathrm{~min}$ with $4.2 \mathrm{mmol} / 1$ glucose then for $60 \mathrm{~min}$ with 8.4 or $16.8 \mathrm{mmol} / 1$ glucose and, finally for $30 \mathrm{~min}$ with $4.2 \mathrm{mmol} / \mathrm{g} \mathrm{glu}-$ cose. The perfusion fluid was collected at either one or five min intervals in refrigerated tubes. Insulin secretion rate was expressed as $\mathrm{ng}$ insulin $/ \mathrm{min} / \mathrm{pancreas.}$

\section{Insulin Extraction}

The technique used for pancreatic insulin extraction was that of Best and Ridout [4] as modified by Rishi et al. [5].

\section{Insulin Determination}

Insulin was measured by a charcoal-separation method of radioimmunoassay [6]. The antibody used was guinea-pig anti-beef insulin antiserum. ${ }^{125}$ I insulin was purchased from C.E.A. (France). Samples were tested using a rat insulin standard (kindly supplied by
Dr. Schlichtkrull, Novo Research Institute, Denmark). For values lower than $1 \mathrm{ng} / \mathrm{ml}$ the sensitivity of the assay was $0.12 \mathrm{ng} / \mathrm{ml}$ with a coefficient of variation equal to $21 \%$; for values lower than $5 \mathrm{ng} /$ $\mathrm{ml}$ the sensitivity was $0.52 \mathrm{ng} / \mathrm{ml}$ with a coefficient of variation equal to $6.8 \%$. Chromatography on a Sephadex $\mathrm{G}-50$ fine column showed the insulin monomer to be predominant in plasma, perfusate and pancreatic extracts of the dormouse. Since dilution curves of the pancreatic extracts from the edible dormouse could be superimposed on the rat insulin curve, it appears that the antibody does not discriminate between the two insulins and that the rat insulin can be used as standard [7]

\section{Calculations}

All results are expressed as mean \pm standard error of the mean (SEM). Statistical evaluation was performed using the Student's $t$ test for non-paired data.

\section{Results}

\section{Weight and Insulin Content of the Dormouse Pancreas (Table 1)}

Weight and insulin content of the pancreas changed according to the seasons. The weight was lower in spring than in winter, it remained low in summer and increased in autumn. The highest hormonal content was present in winter; the average was about $80 \mu \mathrm{g}$ per pancreas. In spring, it decreased to $57 \%$, then it increased in summer and in autumn. This increase was statistically significant between spring and autumn only $(\mathrm{p}<0.05)$.

\section{Insulin Secretion by the Edible Dormouse Pancreas}

The dormouse insulin secretion induced by the two stimulating glucose concentrations were biphasic in all four seasons (Figs. 1 and 2). The first phase lasted about $5 \mathrm{~min}$; the second phase appeared immediately 

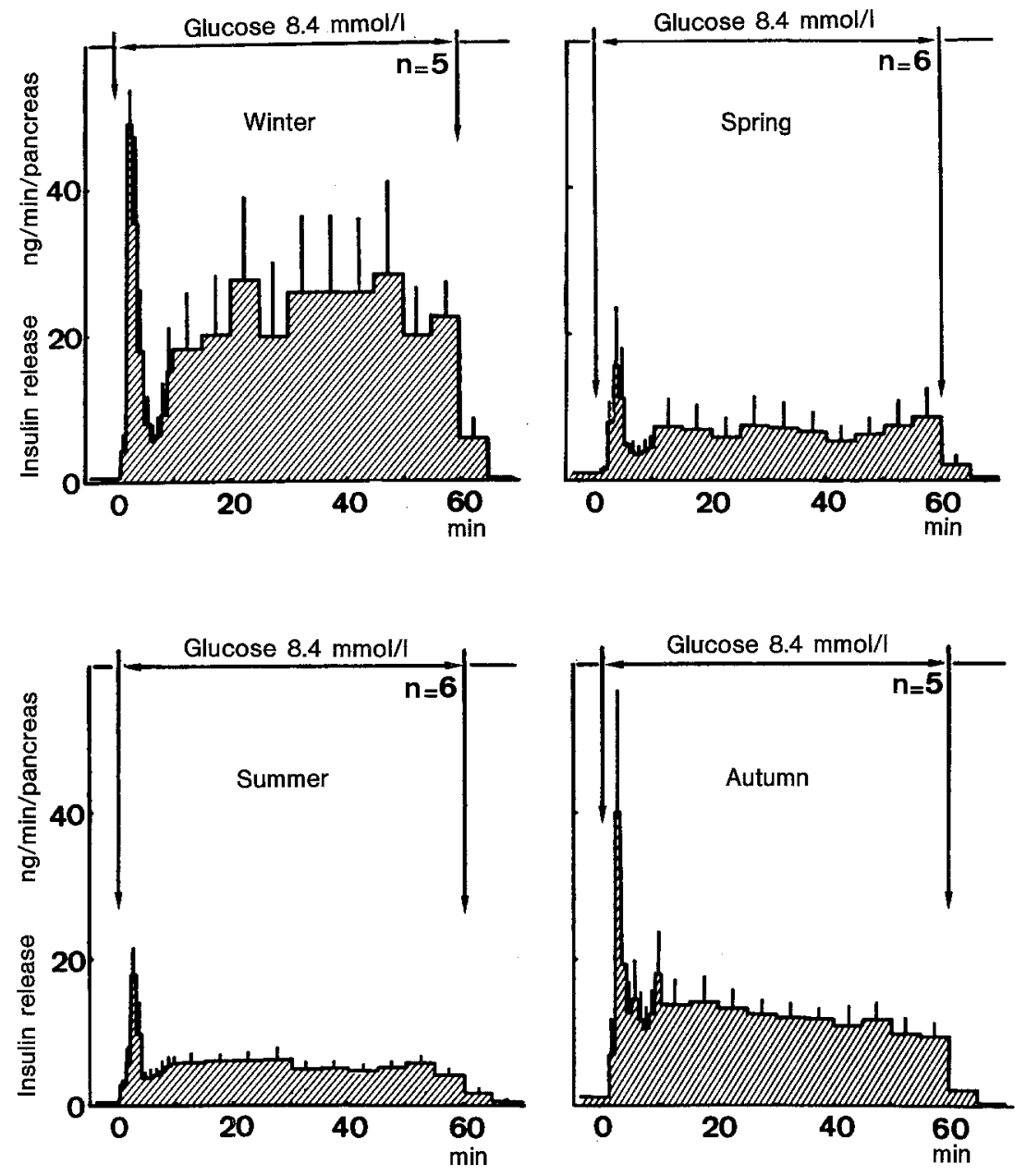

Fig. 1. Seasonal variations of insulin release by edible dormouse pancreas. Perfusion with glucose $4.2 \mathrm{mmol} / \mathrm{l}$ for $30 \mathrm{~min}$ (last 5 min shown) followed by an increase to $8.4 \mathrm{mmol} / 1$ then a return to $4.2 \mathrm{mmol} / 1$ for $20 \mathrm{~min}$

afterwards and a plateau was reached in a few minutes and maintained for so long as the glucose stimulus was continued. At the plateau, the average insulin flow with $16.8 \mathrm{~mol} / \mathrm{l}$ glucose was $30.8 \pm$ $12.6 \mathrm{ng} / \mathrm{min}$ in winter, $7.4 \pm 3.2 \mathrm{ng} / \mathrm{min}$ in spring, $13.1 \pm 3 \mathrm{ng} / \mathrm{min}$ in summer and $23.3 \pm 4.4 \mathrm{ng} / \mathrm{min}$ in autumn (Fig. 2). The immediate insulin secretory response to the two glucose concentrations used $(8.4 \mathrm{mmol} / 1$ and $16.8 \mathrm{mmol} / \mathrm{l})$ was not statistically different between seasons. The high glucose concentration increased statistically $(\mathrm{p}<0.05)$ the late phase of insulin secretion only in summer (Table 2). The total amount of insulin secreted by the two glucose concentrations was greatest in winter. The immediate and late phases of insulin secretion decreased in spring and were stabilized at the lowest level in summer. In autumn, the amount of secreted insulin increased significantly except for the first phase of the $8.4 \mathrm{mmol} / \mathrm{l}$ glucose induced secretion (Table 2). The $16.8 \mathrm{mmol} / 1$ glucose induced insulin release, expressed as percent of the insulin content of the pancreas represented $2.23 \pm 0.31 \%$ in winter, $1.28 \pm 0.1 \%$ in spring, $1.56 \pm 0.15 \%$ in summer and $2.6 \pm 0.11 \%$ in autumn.

\section{Response of Edible Dormouse Pancreas to Two Successive Glucose Stimulations (Fig. 3)}

In order to verify the viability of B cell in our experimental procedure, the pancreas was submitted to a new square-wave increase of glucose concentration from $4.2 \mathrm{mmol} / \mathrm{l}$ to $16.8 \mathrm{mmol} / \mathrm{l}$ at the end of the perfusion time. This high glucose stimulus induced a new insulin secretion comparable to that obtained by the first stimulation. The response disappeared upon cessation of the glucose stimulus.

\section{Insulin Secretion by the Perfused Rat Pancreas (Fig. 4)}

Insulin secretion induced by $16.8 \mathrm{mmol} / \mathrm{l}$ glucose was biphasic. The first phase of secretion lasting about 

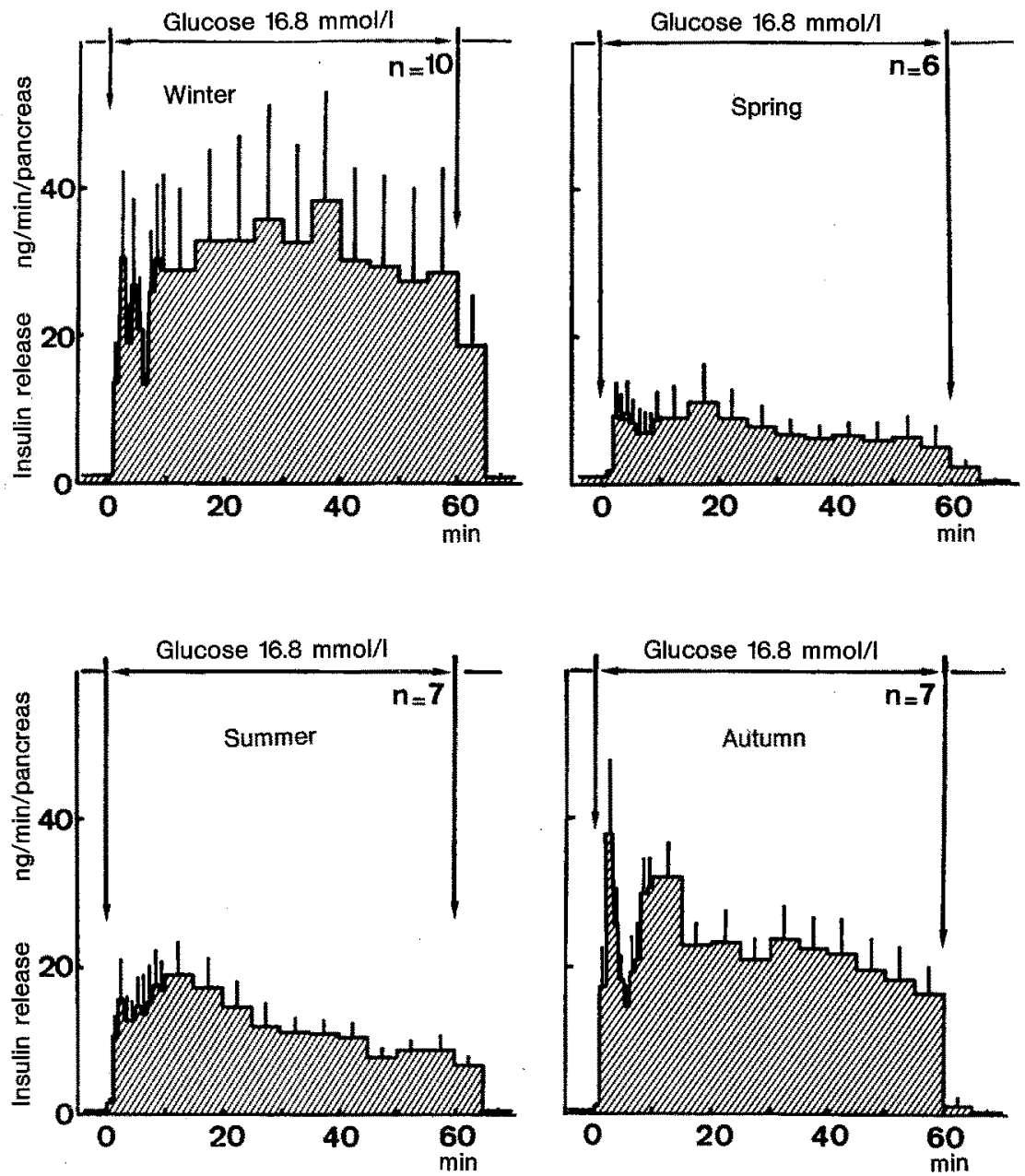

Fig. 2. Seasonal variations of insulin release by edible dormouse pancreas. Same conditions as Figure 2 except glucose stimulus was equal to $16.8 \mathrm{mmol} / \mathrm{l}$

Table 2. Seasonal variations of total amount of secreted insulin (ng). Results are given as mean values $\pm \mathrm{SEM}$; $\star p<0.05$; $\star \star p<0.01$ between seasons; $\dagger p<0.05$ between the two glucose concentrations induced insulin release by student's $t$ test

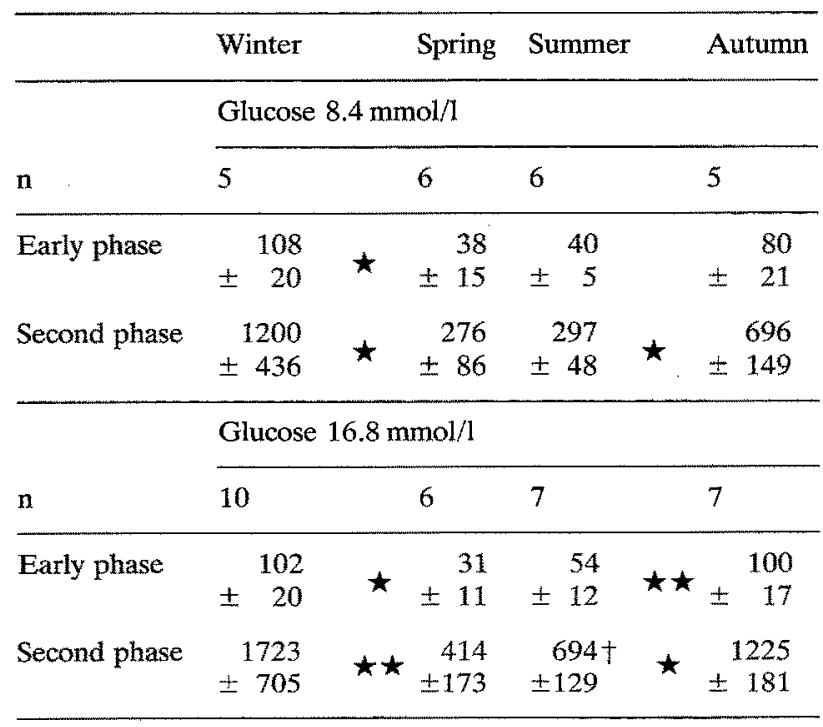

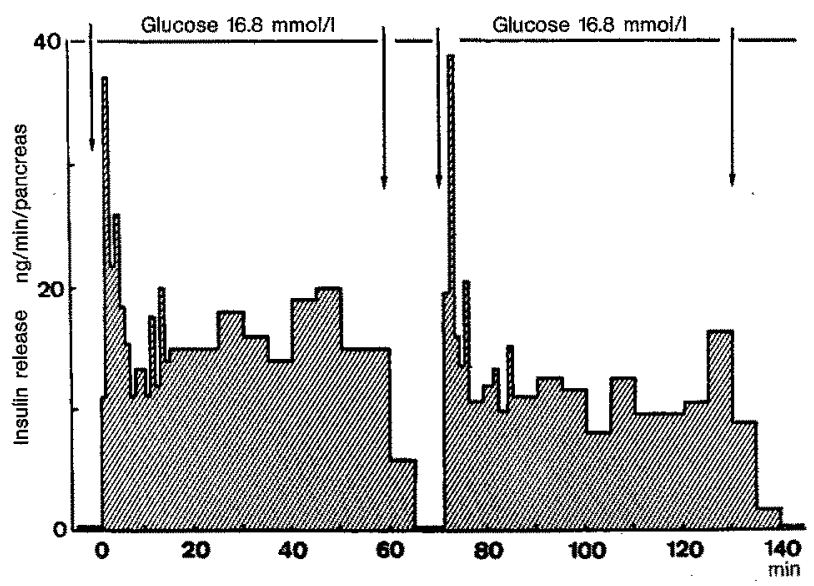

Fig. 3. Insulin release by 2 edible dormouse pancreases. The data illustrate time course of insulin secretion in response to 2 separate glucose stimuli $(16.8 \mathrm{mmol} / \mathrm{l})$. Data obtained in autumn " ". 


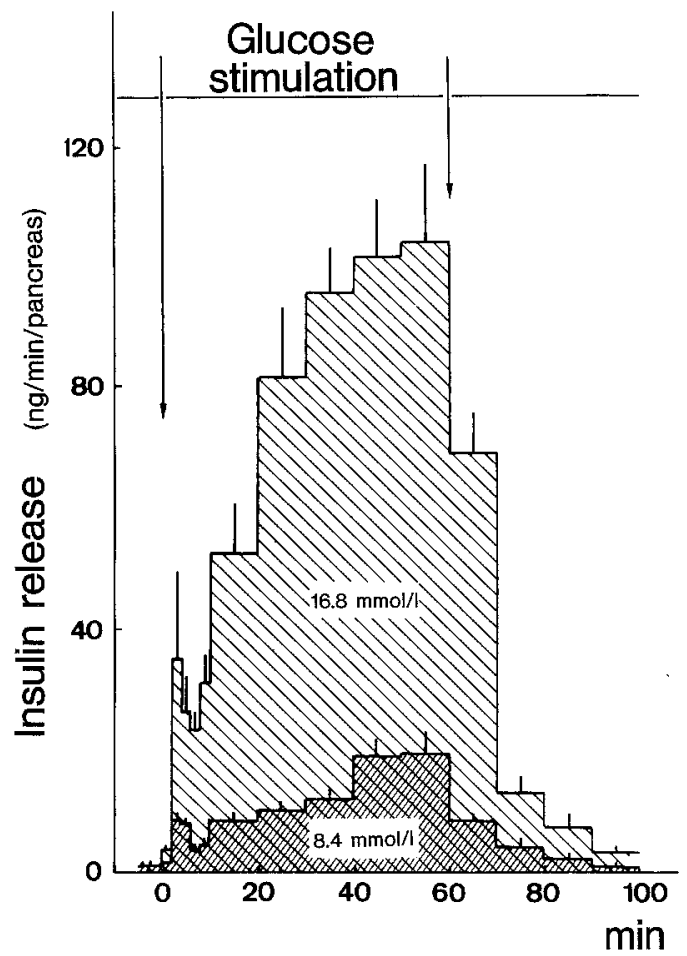

Fig. 4. Insulin release by rat pancreas preparations. Pancreases were perfused with glucose $4.2 \mathrm{mmol} / \mathrm{l}$ for $20 \mathrm{~min}$ (last $5 \mathrm{~min}$ shown) followed by an increase in the perfusion medium glucose concentration to $8.4(\mathrm{n}=5)$ or $16.8 \mathrm{mmol} / 1(\mathrm{n}=13)$, finally a return of medium glucose to $4.2 \mathrm{mmol} / 1$ for $40 \mathrm{~min}$

five minutes, was followed by a second phase which continued to increase for 40 minutes and then remained constant until the end of glucose stimulation. Insulin secretion induced by glucose $16.8 \mathrm{mmol} / \mathrm{l}$ was about 5 times greater than that induced by 8.4 $\mathrm{mmol} / 1$ glucose.

\section{Discussion}

\section{Viability of the Pancreatic Preparation}

Pancreatic perfusion techniques need viability criteria to allow an exact interpretation of the phenomena observed [8]. Thus the perfused pancreas must always be able, to react to a glucose load by a rapid insulin release. As shown in Figure 3, our preparation fullfills this criterion, as the high glucose concentration in the perfusate at the end of the experiment caused an immediate increase in insulin secretion. The pressure values, which correspond to those measured by Luyckx [9] in the rat, never provoked vascular resistance and no oedema of the gland could be observed. The circulatory flow used was sufficient to ensure an adequate oxygenation of the tissue.

\section{Comparison of Insulin Secretion of the Perfused Rat and Edible Dormouse Pancreases}

Glucose-induced insulin secretion was biphasic in both species studied. Qualitative and quantitative differences were however observed in the second secretory phase. The perfused rat pancreas presented a second phase of insulin secretion which increased progressively with high glucose concentrations, as also observed by others $[10,11,12,13]$. In the dormouse, a constant insulin flow in the late phase was rapidly reached. Several animals present similar properties of insulin secretion as the dormouse: the non-diabetic Chinese hamster [14], the Syrian hamster [15] and the mouse [13, 16, 17] also failed to show a rising second phase. In the dormouse the glucose-stimulated insulin increase was much more discrete than in the rat. In the rat, insulin secretion induced by $16.8 \mathrm{mmol} / 1$ glucose was 5 times greater than that induced by $8.4 \mathrm{mmol} / 1$ glucose (Fig. 4), whereas in the dormouse there was little difference in insulin secretion at these two glucose concentrations. Thus $8.4 \mathrm{mmol} / \mathrm{I}$ glucose seemed to stimulate the B cells at a maximum level. The perfused pancreas preparation of the dormouse satisfied the viability criteria; thus the differences observed in insulin release between the two species, must have their origin in specific functional phenomena. In fact, there are differences between species in the B cell sensitivity to glucose, which are now inexplicable [2].

\section{Seasonal Variations in Insulin Secretion by the Edible Dormouse Pancreas}

Seasonal variations in insulin secretion by the perfused dormouse pancreas may be related to the pancreas insulin content. Secretion and hormonal content varied similarly during the annual cycle: they were high in autumn and winter, and low in spring and summer. Malaisse et al. [18] have shown that glucose-induced insulin secretion is proportional to insulin content in the rat. If insulin secretion is expressed as percent of the pancreatic insulin content, it decreases in spring and summer; this cannot be explained only by the low insulin content. Indeed, in spring, when the content is lowest, the available hormone is sufficient to allow insulin release much greater than that measured. So it can be postulated that, in spring and in summer, the dormouse B cell is less sensitive to glucose than during the other seasons. The seasonal variations of the insulin secretion of the isolated perfused dormouse pancreas are in 
good agreement with the plasma insulin level modifications following an intraarterial glucose injection [1]: these levels decrease strongly from March and remain low until July. The decreased B cell sensitivity to glucose of the edible dormouse may also explain the impaired glucose tolerance and the alteration of the glucose oxidation of the adipocytes in spring and summer [19].

Acknowledgements. We are very grateful to L. Duvert for her technical assistance, to M.-H. Davant for typing the manuscript and to Novo Laboratories (Kobnhagen and Paris).

This study was supported, in part, by A.T.P. Ecophysiologie $\mathrm{N}^{\circ} 3570$, A.I. $\mathrm{N}^{\circ} 2523$ (C.N.R.S.) and the Fondation pour la Recherche Médicale Française.

We wish to thank Dr. W. J. Malaisse for a critical review of the manuscript and helpful suggestions.

\section{References}

1. Castex Ch, Donnio R, Sutter BChJ (1979) Seasonal variations of plasma glucose and insulin concentrations after glucose loading in the edible dormouse (Glis glis). J Physiol (Paris) 75: 283-288

2. Feldman JM (1979) Species variations in the islets of Langerhans. Diabetologia 16: 1-4

3. Penhos JC, Wu CH, Basabe JC, Lopez N, Wolff FW (1969) A rat pancreas-small gut preparation for the study of intestinal factors(s) and insulin release. Diabetes 18: 733-738

4. Best CH, Ridout JH (1939) Diet and insulin content of pancreas. J Physiol (Lond) 97: 107-109

5. Rishi S, Golob EK, Becker RL, Shah N (1969) Pancreatic insulin content of non-pregnant, pregnant and post-partum rate and the developing rat fetus. Diabetes 18: 268-272

6. Herbert V, Lau KS, Gottlieb CW, Bleicher SJ (1965) Coated charcoal immuno-assay of insulin. J Clin Endocrinol Metab 25: $1375-1384$

7. Castex Ch, Hoo-Paris R, Donnio R, More J, Sutter BChJ (1978) Determination of insulin levels of the edible dormouse and the hedgehog with reference to the rat. Comp Biochem Physiol [A] 59: 285-289

8. Ross BD (1972) Perfusion techniques in biochemistry, a laboratory manual. Oxford University Press, Oxford, p 496
9. Luyckx A (1974) Sécrétion de l'insuline et du glucagon. Etude clinique et expérimentale. Masson et Cie, Paris, p 338

10. Curry DL, Bennett LL, Grodsky GM (1968) Dynamics of insulin secretion by the perfused rat pancreas. Endocrinology 83: $572-584$

11. Leclercq-Meyer V, Marchand J, Leclercq R, Malaisse WJ (1976) Glucagon and insulin release by the in vitro perfused rat pancreas. Influence of the colloid composition of the perfusate. Diabete Metab 2: 57-66

12. Billaudel B, Sutter BChJ (1979) Direct effect of corticosterone upon insulin secretion studied by three different techniques. Horm Metab Res 11: 555-560

13. Lenzen $S(1979)$ Insulin secretion by isolated perfused rat and mouse pancreas. Am J Physiol 5: E391-E400

14. Gerhard SE, Ruhl M (1974) Insulin secretion of the isolated perfused pancreas of the Chinese hamster (Cricetulus griseus). Acta Endocrinol (Kbh) 76: 302-318

15. Curry DL, Bennett LL, Li CH (1975) Dynamics of insulin release by perfused hamster (Mesocricetus auratus) pancreas: effects of hypophysectomy, bovine and human growth hormone and prolactine. J Endocrinol 65: 245-251

16. Berglund O, Frankel BJ, Heliman B (1978) Development of the insulin secretory defect in genetically diabetic $(\mathrm{db} / \mathrm{db})$ mouse. Acta Endocrinol (Kbh) 87: 543-551

17. Berglund O (1980) Different dynamics of insulin secretion in the perfused pancreas of mouse and rat. Acta Endocrinol (Kbh) 93: 54-60

18. Malaisse WJ, Malaisse-Lagae F, King S (1968) Quantitative and qualitative aspects of the islet function in the rat. $\mathrm{J} \mathrm{Lab}$ Clin Med 71: 56-64

19. Castex Ch, Sutter BChJ (1979) Seasonal variations of insulin sensitivity in edible dormouse (glis glis) adipocytes. Gen Comp Endocrinol 38: 365-369

Received: March 3, 1980, and in revised form: October 3, 1980

Dr. Ch. Castex

Laboratoire d'Endocrinologie

Université de Bordeaux I

U.E.R. de Biologie

Avenue des Facultés

F-33405 Talence Cédex

France 